
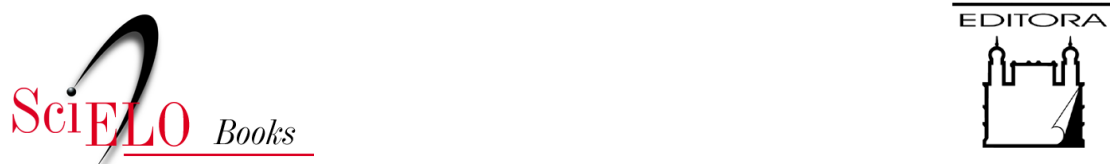

FIOCRUZ

\title{
6. "Será que é? Será que não é?" a perspectiva dos atendentes
}

Armelle Giglio-Jacquemot

\section{SciELO Books / SciELO Livros / SciELO Libros}

GIGLIO-JACQUEMOT, A. "Será que é? Será que não é?": a perspectiva dos atendentes. In: Urgências e emergências em saúde: perspectivas de profissionais e usuários [online]. Rio de Janeiro: Editora FIOCRUZ, 2005, pp. 99-120. Antropologia e Saúde collection. ISBN: 978-85-7541-378-4. https://doi.org/10.7476/9788575413784.0008.

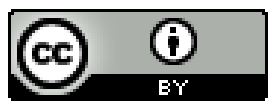

All the contents of this work, except where otherwise noted, is licensed under a Creative Commons Attribution 4.0 International license.

Todo o conteúdo deste trabalho, exceto quando houver ressalva, é publicado sob a licença Creative Commons Atribição 4.0.

Todo el contenido de esta obra, excepto donde se indique lo contrario, está bajo licencia de la licencia Creative Commons Reconocimento 4.0. 


\section{6 \\ "Será que É? Será que Não É?": a perspectiva dos atendentes}

Distante do pronto-socorro, onde suas ambulâncias não param de chegar, fica a Central telefônica de Atendimento às Urgências/Emergências - dita mais simplesmente, Central de Ambulâncias, ou ainda, 192. Agentes importantes da triagem das urgências, seus dois atendentes trabalham apenas durante o dia; à noite, são os próprios motoristas de ambulância que atendem as chamadas telefônicas.

Quando começaram a atuar no 192, nenhum dos dois atendentes tinha sido formado para esse tipo de trabalho. Aliás, desde o início, seus cargos declarados não refletem sua função e responsabilidade reais, a saber: atender as chamadas e triar os pedidos de ajuda, pois eles são, respectivamente, 'mensageiro' e 'escriturária'.

O mesmo pode ser dito dos motoristas da Central que são muito mais do que deixa inferir seu cargo oficial. ' Não só dirigem os veículos, mas têm fornação em suporte básico de vida, entram nas casas dos pacientes, cuidam deles até sua chegada no pronto-socorro, negociam com os que são recalcitrantes, ${ }^{2}$ acalmam com bastante habilidade a violência e o desespero, atendem as chamadas à noite, consertam as ambulâncias etc., sem esquecer o que se tornou, por força das circunstâncias, sua grande especialidade: fazer partos, pois muitos nenês nascem nas ambulâncias do 192. Com o salário e o cargo declarado que têm, não recebem reconhecimento pelo verdadeiro trabalho que cumprem, exceto, em certa medida, pelos partos praticados, objetos de artigos na impressa local e, às vezes, de votos de congratulações da Câmara Municipal.

Porém, sem as múltiplas competências desses motoristas polivalentes, a Central não funcionaria. Se eles só dirigissem e os atendentes-triadores só fizessem o trabalho de um mensageiro e de uma escriturária não haveria atendimento nenhum no 192 . A Central só atende a população à proporção que todos seus profissionais usam de competências que foram desenvolvendo na experiência das funções reais que desempenham. Nessas condições, não é de se estranhar que motoristas e atendentes não se sintam reconhecidos em seu justo valor: nem pela população que valoriza muito mais o Resgate do Corpo de Bombeiros, nem pela prefeitura e nem pela direção do Hospital das Clínicas.

Os magros recursos do 192 e a precariedade material com a qual seu pessoal tem de trabalhar são a tradução concreta de um descaso real. Por exemplo, não se pode fazer nenhuma ligação direta a partir da Central, a não ser para a telefonista do Hospital das Clínicas. Se precisar telefonar para qualquer outro lugar (polícia, bombeiros), é preciso 
sair à rua e ligar de um orelhão ou pedir para a telefonista do Hospital das Clínicas fazer a !igação.

Os motoristas trabalharam durante anos sem rádio comunicação nas ambulâncias. Andavam pelas ruas sem comunicação com a Central, a não ser ligando de um telefone público. Eles conseguiram os rádios graças à ajuda de algumas empresas privadas da cidade, mas ainda devem descer da ambulância à procura de um orelhão para entrar em contato, por exemplo, com a polícia, quando julgam necessária sua presença no lugar (o que representa uma situação bastante comum). Além disso, as ambulâncias estão sempre no conserto, ${ }^{3}$ e quando os motoristas, depois de certas intervenções, têm de lavar e desinfetar a parte traseira da ambulância (porque está com sangue, por exemplo) fazem-no com uma mangueira na beira da calçada, pois a rua é o ínico lugar do qual dispõe a Central para estacionar seus veículos. Entre estes, múltiplos são os exemplos que revelam a situação de escassez na qual se encontra e atua o 192.

\title{
Formaça dos atendentes e Natureza das Cilamadas
}

Quando começou a trabalhar no 192, o atendente 1 contou com a ajuda do chefe da Central e de uma outra funcionária que lhe explicavam, segundo suas próprias palavras, "como é que atende e os procedimentos":

\begin{abstract}
Entrei como mensageiro na Central de Ambulancia. Quando entrei no hospital tinh a outros cargos para mensageiro... arquivar documentos, levar na diretoria, mandar algum documento da chefia para a diretoria, dessas coisas... mas como tinha uma vaga na Central de Ambulancia sobrando, ai me colocaram na Central de Ambulância.
\end{abstract}

Fazia um mês que trabalhava na Central, quando:

\begin{abstract}
veio a Clara, lá da preventiva, ela veio falar para mim se eu queria fazer um curso junto com o Resgate, que era só os bombeiros, os funcionários do Resgate e eu sozinho, sem nenhum outro funcionário da Central de Ambulância. Ai fizo curso de pronto-socorrismo... Já faz cinco anos.
\end{abstract}

Quando a conheci, a atendente 2 atuava na Central havia um ano. Antes, era escriturária em um laboratório de patologia. Desde a sua chegada, não tinha recebido nenhuma formação na área médica, nenhum curso de pronto-socorrismo. Conta que foi o atendente 1 que "ensinou" para ela: "Eu fui assim, pegando com ele! Vendo que pergunta que ele faz".

Os atendentes recebem ligações e pedidos de várias ordens: entre eles, os ligados a questões de saúde. Os erros e trotes são muito numerosos. Os primeiros são de todo tipo: erros na discagem de outros números parecidos; telefonemas provenientes de outros estados do Brasil para saber do tempo, para falar com um particular; erros de encaminhamento da própria central telefồnica etc... Os trotes acontecem por parte de adultos e, sobretudo, de crianças em horários que geralmente correspondem à saída das escolas. O 192 sendo um número gratuito, pode-se chamar sem custo de qualquer orelhão. Eis alguns exemplos de erros e de trotes bastante comuns: 
Erros

A: - Central de Ambulância, bom dia!

S: - Você tem o número de telefone da central de artigo de pesca?

A: - Não. Você tem de ligar pro 102, informações.

S: - Obrigado.

A: - De nada.

A: - Central de Ambulância, boa tarde!

S: - Olha, eu quero saber do número a cobrar.

A: - Eu não sei, informaçôes é 102.

S: - Quê?

A: -102 .

S:- 109 ?

A: -102 .

S: - Está bem, obrigada!

( $\mathrm{S}=$ Solicitante; $\mathrm{A}=$ Atendente)

Trote:

A: - Alô?

$S$ [criança]:-Quem fala?

A:- Com quem quer falar?

S: - Com o senhor.

$\mathrm{A}:-\mathrm{Oi}$ ?

S: - Alô, quem fala?

A: - Com quem você quer falar?

S: - Com o José.

A: - Não tem nenhum José aqui não.

S: - É o senhor.

A: - Oh! Você pára de encher a paciência aqui, porque senão eu vou mandar a policia ir pegar você aí?

S: - Hein?

A: - Eu vou mandar a PM dar uma passadinha aí para ver o que está acontecendo.

[A criança desliga].

$(\mathrm{S}=$ Solicitante $\mathrm{A}=$ Atendente $)$

O que cai de menos na Central são chamadas diretamente ligadas a problemas de saúde. E se delas ainda se extraem pedidos de transferência de um paciente para outro 
hospital, e aqueles cujo atendimento é da competência declarada do Bem-Estar Social ${ }^{4}$ (serviço social da prefeitura), chega-se à conclusão que as solicitações de ajuda urgente para problemas de saúde e acidentes representam a minoria das chamadas recebidas pela Central, cuja função declarada é atender as urgências e as emergências, como está escrito em suas ambulâncias. Mesmo assim, essas chamadas não deixam de ser numerosas.

\section{A Triacem pelo Telefone}

A partir do que diz o solicitante, os atendentes tentam identificar o problema de saúde e avaliar seu nível de gravidade para saberem se há urgência ou não em mandar uma ambulância. À diferença dos vários agentes da triagem que atuam no prontosocorro, eles não podem se basear em nenhum elemento visual de apreciação. Só dispõem da fala dos solicitantes. Além disso, também procuram discernir se o pedido não é falso. Sendo numerosos os trotes recebidos pela Central, essa preocupação não é secundária. A avaliação dos atendentes da Central, então, é dupla: visa a identificar não somente sinais de urgência, mas também eventuais indícios de mentira.

\section{INSEGURANÇA}

Como as recepcionistas do pronto-socorro do Hospital das Clínicas, os atendentes da Central de Ambulâncias lembram o quanto ficavam perdidos no início, isto é, o quanto era árduo saber "o que é" e "o que não é":

Mais dificil no inicio era a emergência mesmo, que era essa parte de enfarte, gestante... já não... Na hora, sim, posso anotar, aguardar, só que eu não tinha noção da gravidade. Mas depois que fiz o curso [de pronto-socorrismo], ai já fiquei mais assim... conhecendo o curso ai já melhorei. Mas antigamente o que eu tinha mais preocupação, era a parte de emergência mesmo... Para reconhecer na chamada... A pessoa ligava para a gente aqui, eu ficava assim... Seráque é? Será que não é?... Ficava na dúvida, não sabia mais ou menos assim o que estava acontecendo do outro lado da linha. Ai com esse curso que eu fiz com a Clara, já deu para ter noção. (....) Tem os trotes também. Puxa! Às vezes, eu fico até assim... Na hora que estou conversando com a pessoa, estou achando que é trote. No começo era assim. Achava tudo trote. Depois é que eu comecei a conversar bastante com a pessoa. Eu faço de novo as mesmas perguntas para ver se a pessoa responde igual. (...) Emergência, você tem que conversar bastante com a pessoa, ver o que está acontecendo. Às vezes, eu fico assim na dúvida... será que é? (...) Eu entrei aqui como mensageiro... No começo... eu conversava com a pessoa, eu achava que não era nada. Depois que eu fiz o curso lá, com os professores da faculdade, que eu vi que podia ser coisa mais... assim... grave, mais de... responsabilidade mesmo. (Atendente 1)

No começo, eu achava assim, que toda chamada fosse urgente, Quando eu pegava o telefone, estava meio perdida, eu achava que tudo era urgente. Ai, com 
o tempo, fui percebendo que coisinhas corriqueiras, que podem até esperar um pouco mais, você pode segurar um pouco mais, não é! (...) Coisas corriqueiras, febre, dor de barriga, dor de cabeça, dor abdominal... Um machucado, cortou o pé assim, não grave, um corte simplesmente (...) Agora dá para saber melhor, agora, sim. Tipo assim, o que é mais urgente ou não é! O que é mentira também. Pelo telefone. Só que eu acho que não é o ideal, não é! O certo é você ir lá e constatar. (Atendente 2)

No início, então, um julgava que tudo era 'trote' ou 'nada', enquanto a outra achava tudo "urgente'. Mas, afirmam os dois, "com o curso" ou "com o tempo", chegaram a identificar melhor "o que é" e "o que não é". Hoje, sentem-se mais firmes e tranqüilos na triagem e na conseqüente decisão de mandar, com ou sem pressa, as ambulâncias. Entretanto, eles concordam que, mesmo assim, há vezes em que ficam na dúvida e que, afinal, nunca dá para saber, com certeza, "o que acontece do outro lado da linha":

Muitas vezes não dá para saber o que é. Que nem essa ligação agora. Se fosse um médico, ele iria falar que é... sei lá... pode ser problema que ela teve bebê ou estava com infecção por dentro, acabou... Eu mesmo se fosse médico... Deveria ter um médico como triador, não um mensageiro. (Atendente 1)

No fundo, você nunca sabe se é ou não é. Mas assim, pelo conversar com as pessoas... então você sabe aquilo que você manda primeiro, aquilo que você acha que pode esperar um pouquinho mais... assim você tem que mandar, não é? Porque desde que ligou, você tem que mandar, tem que dar a prioridade àquilo que você acha um pouco mais.., pelo que você conversou com ela... apesar que eu acho que pela triagem não dá para saber. Tem que ir no local e ver. (Atendente 2)

Os atendentes sabem que seus meios de avaliação são limitados: de um lado, pela ausência de informações visuais que caracteriza sua triagem; do outro, pela falta de competência médica que sentem e que ainda aumenta seu sentimento de insegurança e suas dúvidas.

\section{Meios de Idfantificaçĩo e Critérios de Apreciaç̃̃o}

Apesar das dúvidas, os atendentes da Central de Ambulâncias não deixam de tomar decisões em resposta aos pedidos de ajuda. Quais são, então, as técnicas que foram desenvolvendo para reconhecer um trote e identificar uma possível urgência no telefone? E quais são as informações e os sinais para eles significativos?

Os atendentes insistem na importância de suas conversas com os solicitantes. Procuram alimentá-las e orientá-las de maneira a obter dados sobre o problema que motiva a chamada e a recolher o conjunto de informações indispensáveis para o envio de uma ambulância (nomes do solicitante e do paciente, localização de endereço), ${ }^{5} 0$ que não é sempre fácil, como veremos. 
Os sinais e os meios de verificação que levam os atendentes a discernir uma chamada séria de um trote são na maioria das vezes muito sutis, tendo em vista que só contam com a voz e os dizeres do solicitante. Desse modo, distinguir uma chamada séria de uma brincadeira despropositada requer experiência, como pude constatar ao escutar as conversas entre solicitantes e atendentes no telefone:

Quanto ao trote, eu percebo quando a pessoa começa a gaguejar um pouco... ou mesmo no nome... não fornece mais detalhes do problema e fica batendo na mesma tecla, não dá pormenores. Que dá a entender que não é real. Pois às vezes não bate coisa com coisa. 'Dor de cabeça?, Desde que horas?, E tomou alguma coisa?', Fez isso?, Fez aquilo?', sabe! Então eu percebo assim, se é um trote... Já começa no horário. Não bate nada com nada. Se tomou alguma coisa, às vezes não é o remédio certo para aquilo, tipo assim. (Atendente 2)

A maioria dos trotes que liga aqui, a pessoa passa o nome da rua, só que é de outro bairro, não tem nada ver. A maioria dos bairros aqui de Marilia, eu conheço todos jả. No inicio, tinha dificuldade, tinha que olhar no mapa, confirmar pelo mapa. Agora não, se você me perguntar qualquer rua, te falo qual bairro que é. Só se for um bairro novo de casas populares que não dá para saber. Então às vezes eu pergunto para a pessoa 'o que está acontecendo?', 'ah, fulano de tal desmaiou', 'mas o senhor sabe qualé o problema dele, tem problema de desmaio, tem problema de sauide grave, faz algum tratamento?', essas coisas. Ai a pessoa vai falando. Ai no fim, 'você sabe o nome dele completo?', 'é, é senhor fulano', 'mas o quê você é dele?', se ele diz 'sou irmão', 'e você não sabe o sobrenome?', ai fico naquela divida, vocè não sabe se é parente, se é vizinho, ai você vai conversando com a pessoa, vai fazendo de novo as mesmas perguntas para ver se a pessoa responde a mesma coisa ou eu digo: 'dá para aguardar, não tenho ambulância'; às vezes eu falo: 'não tem ambulância na hora', mas a ambulância está aqui, eu falo só para ver a reação da pessoa do outro lado, para ver se tem uma pessoa realmente desmaiada.. estou testando para ver se não é trote mesmo. (Atendente 1)

Fora os trotes, há também as chamadas dos solicitantes que exageram e até inventam os sintomas para conseguir ou apressar a chegada da ambulância no lugar; ou, ainda, que evitam assinalar elementos que poderiam inviabilizar sua disponibilização. Agem assim, muitas vezes, porque estão com receio de seu pedido não ser atendido (ou ser atendido sem pressa) se contarem o verdadeiro problema (o paciente está alcoolizado, por exemplo) ou se revelarem o motivo real da chamada (o paciente não está mal, mas quer ir ao pronto-socorro fazer uma consulta). Esses solicitantes fazem uma descrição mais assustadora do que é na realidade o estado da pessoa para quem ligam: dizem que está desmaiada, que não pode ficar em pé, que bateu a cabeça, que está sangrando, sintomas que, de fato, mobilizam a atenção dos atendentes, tendo em vista que os consideram como possíveis sinais de um problema grave.

As pessoas usam o lado exagerado da coisa para ter uma ambulância. Por exemplo, uma febre: 'ah, está com tantos graus!'. O que leva a uma convulsão, tal... No caso de diarréia, fraqueza: 'não está parando em pé', 'tem que ir' e tal... 
Coisas que, na verdade, você não sabe se é real ou não por telefone, mas eles usam assim, o lado exagerado da coisa. (Atendente 2 )

A pessoa te diz: 'ah, está desmaiado!'. Você chega lá, não está desmaiado. Às vezes, a pessoa mente no telefone para que a ambulância chegue mais depressa no local. (Atendente 1)

Numerosas são as saídas de ambulâncias enviadas para um caso cuja descrição preocupante tem pouco a ver com a situação real, descoberta uma vez no lugar. Por exemplo, é comum a Central ser acionada para mulheres grávidas de 9 meses, descritas como estando para dar a luz, na cama com muitas dores e, quando a ambulância chega ao lugar, as ditas mulheres estarem esperando em pé na frente da porta de sua casa, uma sacola plástica na mão com suas coisas, aparentemente bem e todas preparadas para ir ao hospital fazer o parto. Esses casos são tão habituais que os motoristas dão o nome de "sacoleiras" a essas pacientes, por causa da sacola plástica que sempre carregam.

No que diz respeito à avaliação de urgência, os atendentes tentam determinar o problema e sua gravidade por meio de perguntas precisas. Sua apreciação se baseia ao mesmo tempo sobre a situação e os sintomas descritos e sobre o comportamento e as reações do solicitante no telefone cuja atitude os atendentes consideram bastante reveladora. Assim, por exemplo, seu nervosismo é interpretado como sinal de gravidade: a angústia, o desespero que o solicitante passa convence os atendentes de que o problema "não pode esperar". ${ }^{6}$ Eles mesmos afirmam: "Quando a pessoa está realmente nervosa no telefone, é que o caso é de extrema urgência. Aí, eu mando a ambulância na hora" (Atendente 1); "Todo caso grave mesmo que você vê por telefone com a pessoa, a pessoa conversando com você, vê que ela está assim apavorada, desesperada, você vê que é uma emergência, você manda na hora" (Atendente 2).

Mesmo que seja por telefone, você se sente um pouco ao lado da pessoa, a maneira que ela fala para você, se ela está desesperada, é que é grave. Você sente o problema dela assim, tipo 'olha, ele tem isso que é doença grave', tipo 'não está se alimentando, caiu a sonda, não consegue andar, não pára de pé'. Então, mesmo que seja por telefone, você pega um pouquinho desse problema, mesmo que a pessoa do outro lado, você não conhece, mas você sabe que tem pessoas que têm esse tipo de problema. A partir do momento que eu converso, eu sinto a pessoa, o problema dela, que ela passa para mim (...) Então, são coisas do tipo grave, que a gente fica sabendo por meio da triagem. Por mim, se eu tivesse uma ambulância naquela hora, eu quero mandar logo, porque quero que vai logo para curar, para resolver de vez esse problema. Você vê a pessoa chorando ou 'pelo amor de Deus!', sabe! (Atendente 2)

A tranqüilidade do solicitante significa que o problema, apesar de ser apresentado como urgente, não é tão urgente assim e pode esperar. $O$ fato de não pedir, com insistência, a chegada apressada da ambulância, é também interpretada dessa maneira. Tendo provocado a fala do atendente 1 a respeito dessas observações, este confirma e explica: 
Quando eu digo que vai demorar, 'dá para aguardar?'. 'ah, dá para aguardar!', então você vai ver que o desmaio, que ela falou, não é tão grave assim, vai ver que o cara nem é desmaiado. (...) Desmaio dá para aguardar? Não dá. Tem que ir na hora. Então, às vezes, você vê se é emergência ou se não é. Às vezes, uma pessoa desmaiada que a pessoa fala que dá para aguardar meia-hora, uma hora, não é bem desmaiada, deve ser algum mal súbito que deu, depois voltou a si, já está melhor, só está precisando de procedimento médico no hospital. (...) Quando a pessoa fala 'ela está desmaiada aqui, já faz meia hora que ela está desmaiada', ai eu vejo que não é tão assim... Ai eu falo: 'mas como está a pessoa, está desmaiada ainda?'. Eu falo para a pessoa 'ah, não tem ambulância, dá para aguardar?'. E a pessoa fala 'não, não, preciso urgente'; falo 'então, senhora, vê com o Resgate, 193, vê se eles mandam um carro, no momento realmente eu não tenho'. Ai, às vezes, a pessoa fala 'ah, não! Dá para aguardar uma meia-hora, vinte minutos, dá para aguardar'. Então para mim, para mim que converso direto com a pessoa no telefone, no meu sentido, eu acho que não é tão grave assim.

\section{Sinais e 0bstŕculos para a Avaliaçáo}

No que diz respeito, mais especificamente, ao problema de saúde descrito no telefonema, os sinais que mobilizam os atendentes são os que já foram apontados nas outras categorias de triadores. Quando o solicitante fala que a pessoa está desmaiada, inconsciente, que não "pára em pé" ou não anda, que está com febre alta, que sente dor no peito, falta de ar, que caiu, perde sangue, está com alguma coisa quebrada, com muita dor, que se trata de uma mulher grávida, ele chama a atenção dos atendentes que procuram fazer mais perguntas para confirmar ou infirmar a suspeita de gravidade que levantou sua fala.

Eis seis exemplos representativos de chamadas recebidas pela Central que desembocaram na decisão, por parte do atendente, de mandar uma ambulância no lugar com rapidez (Exemplos 1 e 2) e sem pressa (Exemplos 3, 4, 5, 6). Mostram o tipo de perguntas feitas sobre o paciente, sua identidade, estado de saúde e de espírito; sobre o solicitante e o acompanhante, ${ }^{7}$ e também sobre a situação em que ocorreu (se manifestou) o problema. As perguntas visam a precisar a necessidade ou não de uma intervenção rápida.

\section{EXEMPI.0 1:}

A: - Central de Ambulância, bom dia!

S: - Bom dia! Olha, tem uma moça aqui, minha vizinha, está grávida, acho que está para ganhar nenê! Porque ela está com dor e pediu para chamar.

A: - Está de 9 meses?

S: -9 meses.

A: - Está com dor desde que horas?

S: - Desde cedo.

A:- Desde cedo. É o primeiro filho? 
S: -É o segundo.

A: - Quantos anos ela tem?

S: - Acho que é 29, não tenho certeza.

A: - E como ela se chama?

S:- Ana Cristina de Oliveira Silva.

A:- Quem está falando?

S: - Rosa de Oliveira Rubim.

A: - Rubim?

S: - Isso!

A: - Que bairro que é?

$\mathrm{S}:-$ Coimbra!

A: - Que rua que é?

S: - Rua Eduardo Neves, 135.

A: - Ela está com dor e sangramento?

S: - Sangramento não sei.

A: - Já está com 9 meses?

S: - Está.

A: - Está com dor assim, de quantos em quantos minutos?

S: - Direto!

A: - Está bem, então! É só aguardar, estou mandando já.

$\mathrm{S}$ :- Obrigada.

A: - De nada, tchau!

$(A=$ Atendente $; S=$ solicitante $)$

EXEMPIO 2:

A: - Central de Ambulância, boa tarde!

S: - Alô, estou precisando de um cano... [falando para outra pessoa]

A: - Qual é o problema aí, o que está acontecendo?

$\mathrm{S}$ : - Não, minha avó caiu da escada!

A: - Caiu da escada?

$\mathrm{S}:-\dot{E}$, num sobrado.

A: - Está ainda no chão, ou já levantou?

S: - Está no chão desmaiada, bateu a cabeça, ela está bêbada.

A: - Quem está falando?

S:- Hein?

A: - Quem está falando?

S: -É o dono do bar, é o Rodrigo.

A:- Rodrigo do quê? 
S: - Hein?

A: - Rodrigo do quê?

S: - Espera aí, eu estou saindo agora de manhã... [falando para outra pessoa].

A: - Hein?

S: - Eu moro na casa do outro lado, mas que é...é o Jorge Bispo.

A: - E quem que é esse Rodrigo?

S: - Rodrigo é o dono do bar. Você quer ainda resgatar ou não?

A: - Não?! Também o senhor precisa fazer minha folha de ambulância para mandar a ambulância aí. Que rua que é?

S:-Rua Presidente Vargas, n.53.

A: - Rua Presidente Vargas, n.53. Está ok! Vou mandar uma ambulância aí para resgatar a paciente.

S: -45 .

A: -53 ou 45 ?

S: -45 .

A: - Está bom, então! O senhor aguarde aí com ela.

S: - É expresso ou não?

A: - Eu vou mandar, estou mandando.

S: - Vou comprar...

A: - O senhor vai aguardar ou vai deixar alguém aí?

S: - Não sei! Porque o rapaz estava se estrebuchando no chão, bateu a cabeça!

A: - O senhor é que sabe, já estou mandando a ambulância.

S: - Então, manda já, então!

A: - Está bem!

$(A=$ Atendente $;=$ solicitante $)$

Exillolo 3 :

A: - Central de Ambulância, boa tarde!

$\mathrm{S}:-\mathrm{E}$ para meu filho.

A: - O que que ele tem?

$S$ : - Está com falta de ar.

A: - Ele está com falta de ar há quanto tempo?

S: - Desde ontem.

A:-Desde ontem à noite?

$\mathrm{S}:-\dot{\mathrm{E}}$.

A: - Você já levou ele em algum centro de saúde ou não?

$\mathrm{S}:-N a ̃ o$, ainda não!

A: - De que bairro você está falando? 
S: - Jânio Quadros.

A: - Do Jânio Quadros. Ele tem sempre essas crises ou não?

S: - Hein?

A: - Ele tem sempre essas crises?

S: - Sempre teve.

A: - E hoje está bastante atacado?

S:- Está.

A: - Você acha que inalação não vai cortar?

S: $-\ldots$

A: - Quantos anos têm?

S: - Tem 9 anos.

A: - E o posto de saúde, é próximo daí ou não?

$S:-N a ̃ o$, fica tão longe!

A: - Você não quer levar primeiro esse menino no posto de saúde e de lá entregaria para a gente?

S: - Não. Levo esse menino direto para as Clínicas.

A: - Porque você não leva no posto?

S: - Não, não!!!

A: - Você não confia no posto?

S: - Eu, não. Sempre levei para as Clínicas.

A: - Um minutinho então, eu vou anotar. Qual é o seu nome?

S: - Cilé.

A: - E o nome da criança?

S: - Pedro...

A:- Que rua que é?

S: - Rua Francisco Xavier de Moraes.

A: - Onde fica?

S: $-\ldots$

A: - Que número?

S: -1513 .

A: - Rua Francisco Xavier de Moraes.

$\mathrm{S}:-$ é.

A: - Então, está bom! É favela ou não?

S: - Não, é uma chácara!

A: - Então está bem, a gente manda aí. Deixa ele prontinho.

S: - Está bom!

A: - Até logo.

$(\mathrm{A}=$ Atendente $; \mathrm{S}=$ solicitante $)$ 
EXEMPIO 4:

A: - Central de Ambulância, bom dia!

S: - Bom dia, por favor, daria para você mandar uma ambulância aqui na Salvador Salgueiron. 340?

A: - O que está acontecendo?

S: - É que tem um senhor que está muito ruim, aqui no fundo!

A:-Qual é o problema dele?

S: - Ah, espera ai só um pouquinho! Qual é o problema mesmo seu Manoel? Ele está muito... Não sei se ele bebeu demais, não sei, acho que tem que internar ele!

A: -É o seguinte, agora não tenho ambulância, vai demorar um pouquinho. Vai ter que me ligar mais tarde!

S: - Vai demorar quantos minutos?

A: - Quarenta minutos, mais ou menos.

S: - Nossa! Mas toda vez que chamo a ambulância demora quarenta minutos. Por que será que acontece isso?

A: - Não tenho ambulância agora!

S: - Só daqui a quarenta minutos, então?

A: - É... é na Salvador Salgueiro, que número que é?

S: -340 , no fundo.

A: - Qual é o problema dele?

S: - É um senhor que, sei lá, acho que bebeu demais, é para internar ele!

A: - Mas quem vai vir com ele?

$\mathrm{S}$ [pergunta a alguém que está perto]: - Quem vai com ele?... Diz que ele vai sozinho!

A: - Não, sozinho não dá para trazer ele. Ele não está inconsciente? Como que ele vai dar os dados na hora que for fazer a ficha?

$\mathrm{S}$ [Falando para outra pessoa]: - Está falando que é para alguém ir junto para dar os dados dele lá no hospital, dar o nome... ele está consciente? Ele pode fazer isso?... Consciente ele está!

A: - Ele quer vir para o hospital?

S [para o paciente]: - Está querendo ir, seu Manoel? Está querendo, ele pediu para chamar a ambulância, para internar ele. Ele mesmo está querendo se internar!

A: - Como que é o nome dele?

S: - Cirço. O sobrenome, eu não sei.

A: - Quem é que está aí do lado conversando com a senhora?

S: - É um rapaz que também mandou chamar a ambulância.

A: - Então... mas ele não sabe o nome completo?

S: - Nós só tratamos ele por Cirço aqui.

A: - E não tem ninguém da família dele que possa passar os dados?

S : - Então, só chamamos ele por Cirço... Vai demorar, então? 
A: - Vai demorar, sim. Então pede para alguém da família dele ligar e passar os dados dele completos, porque precisa do nome completo dele!

S: - Porque quem está telefonando é a presidente da associação de moradores.

A: - Então, preciso do nome dele completo.

$\mathrm{S}:-\mathrm{O}$ nome dele completo?

A: - É!

S:- Só o nome?

A: - É!

S: - Então ele vai ver se pega o nome completo dele. Aí, eu ligo depois.

A: - Está ok!

[Alguns minutos depois]

A: - Central de ambulância, bom dia!

S: $-E$, bom dia! Acabei de ligar aí e o moço pediu o nome do rapaz.

A:- Certo. Qual é o nome dele? Pode falar!

S:-É Cirço Pedro da Silva.

A: - Como? Cirço?

S:-É Cícero Pedro da Silva.

A: - E não tem ninguém para vir com ele, senhora?

S: - Olha, não posso explicar para o senhor, porque eu sou a presidente da associação de moradores.

A: - Mas ele não tem família, senhora?

S: - Ah! Ele mora com a parente dele, mas o marido dela está trabalhando e ela têm bastante criança, não pode estar acompanhando ele!

A:-Mas sabe qual é o problema? O problema é o seguinte, que vem uma pessoa desinformada até o hospital, e aí ele vai ficar lá no banco, minha senhora, o problema é esse!

S: - Ele mesmo está pedindo para ir. Mas é ele mesmo que pediu para chamar a ambulância, porque ele quer ir. Então é uma oportunidade de estar tirando uma pessoa dessa droga, desse vício.

A: Certo! Ele usa...

S: - Se a pessoa está aceitando ir, eu acho que é uma boa idéia!

A: - Ele está usando muita droga?

S: - Não! É pinga, bebida!

A:-É alcoólatra.

S: - É bebida, certo?

A:-Bom, a gente vai fazer o transporte, está bom?

$\mathrm{S}:-$ Vai demorar?

A: - Vai demorar sim, uns 20 minutos.

$\mathrm{S}:-$ Uns 20 minutos?

A: - Isso! 
S: - Então, tem alguém aguardando aqui.

A: - Está ok então, senhora!

$S:-E$ faça o favor, porque ele está querendo ir, acho melhor a gente ajudar.

A: - Está bom.

$\mathrm{S}$ :-Euacho.

A:- Está jóia!

S:- Obrigada!

A: - De nada, tchau!

\section{$(\mathrm{A}=$ Atendente $; \mathrm{S}=$ solicitante $)$}

EXIXIPLO5:

A: - O que é que está acontecendo aí?

S: - É ele está com um problema na costa, está doendo...

A: - Está com dores nas costas? E não sabe porque está sentindo essa dor? Tem algum problema de coluna ou não?

S: - Deve ter, viu! Porque diz que dói!

A: - É a primeira vez que dá isso nele ou não?

S:- Hein?

$\Lambda:-$ Já teve outras vezes?

S: - Já teve mais fraco, dessa vez está mais forte.

A: - Ele está andando ou não?

S:- Está acamado.

A: - Mas ele anda ou não?

S: - Ele anda, mas...

A: - É pessoa de idade?

$\mathrm{S}:-\dot{\mathrm{E}}$.

A: - O nome dele?

S: - Cássio Aparecido Custódio

A: - Cássio Aparecido Custódio... Quem é essa pessoa que vai vir com ele?

S: - Sou eu, Joaquim.

A: - Joaquim do quê?

S: - da Silva

A: - Que rua que é?

S: - Rua João Batista... Terezinha Ferreira... Coloca 'em cima'.

A: - Que número?

S: -189

A: - Dentro da favela?

S: - É pertinho da Nova Esperança. 
A: - E o senhor vai ficar aí, esperando na parte de cima aí?

S: - Isso.

A: $-E$ a rua é asfaltada?

S: - É.

A: - Então o senhor aguarda aí, viu!

S: - Está ok, então! Obrigado!

A: - De nada.

( $\mathrm{A}=$ Atendente $; \mathrm{S}=$ solicitante $)$

EXEMPI0 6:

A: - Central de Ambulância, boa tarde!

S: - Boa tarde! Eu moro na rua Santa Helena, 149, e tem um senhor caído aqui, perto da minha casa, que eu acabei de chegar. E estou ligando do orelhão porque não tenho telefone. Uma vez eu liguei, e não sei se foi para você, e vieram recolher uma pessoa. Eu não sei o que está acontecendo com ele, mas ele não está sangrando e eu queria saber o que é que eu faço?

A: - Quem está falando?

S:-Adriane.

A: - Olha, Adriane, é o seguinte. Você precisa saber se a pessoa está passando mal, se ele está conversando.

S: - Olha, eu não sei de nada, só está caído no chão, não sei se está desmaiado, se está bêbado, ou se está dormindo. Não sei, acabei de chegar!

A: - Não tem como você ver lá o que está acontecendo?

S: - Eu cheguei perto, mas eu não vou mexer. Eu não tenho uma luva, não tenho nada, não sei... de repente a pessoa é agressiva ou não, e se está viva. Eu não vou mexer!

A: - Olha minha senhora, aqui no momento eu estou sem ambulância nenhuma. O que eu posso fazer, é anotar e aguardar. Eu precisava saber se a pessoa está conversando, ver se ele consegue falar ou não.

S: - Conversar, não está conversando, não parece morto, mas também não abre os olhos. A gente passa perto dele, fala com ele, só que ele não responde nada, mas está respirando.

A: - Tem mais alguém com a senhora aí na rua que pode mexer com ele para ver se ele responde.

$S$ : - Não, ninguém, ninguém quer ver.

A: - O que eu posso fazer aqui no momento, é anotar e aguardar.

S: - Faz essa gentileza, faz esse favor para mim!

A: - Como é o seu nome completo?

S: - Adriane... Agora eu não sei se na hora que vocês chegarem, se ele vai estar aqui ainda. 
A: - Então, senhora, por isso é que tem que ver se ele está passando mal e se ele quer ir para o hospital. Vai que manda uma ambulância aí, e ele não quer vir! S: - É! Então deixa, porque eu não vou poder mexer, eu estou muito receosa. Posso até ajudar, mas mexer não.

A: - Tudo bem senhora, mas não tem como alguém fazer isso pela senhora?

$\mathrm{S}$ : - Você não sabe se tem alguma outra entidade da prefeitura que possa fazer isso por mim?

A:-Não. É o seguinte: a Central de Ambulância é urgência e emergência. A gente pede para o solicitante onde está o paciente e ver se ele quer vir, ver se ele não está passando mal. Se estiver passando mal, eu mando a ambulância.

S: - Mas se é uma entidade da prefeitura que dá assistência para as pessoas que ficam jogadas aqui na rua?

A: - Aquele lá é o Bem-Estar Social da prefeitura.

S: - Se eu falar com eles, será que eles vêm buscar?

A: - Então, teria que ver primeiro se ele está passando mal, se quer vir para o hospital. Agora, se ele não estiver e se for um caso de levar para o albergue ou para o Funabes, aí seria com eles.

S: - Então eu vou tentar verificar isso, moço.

A: - Mas qual é o endereço que ele está?

S: - Avenida Santa Helena, 149, está aqui na calçada.

A: - Avenida Santa Helena, 149.

S: - Eu sou manicura e trabalho aqui na frente do orelhão.

A: - Adriane do quê?

S: - Adriane Trindade.

A: - A senhora não quer ver tudo certinho?

S: - Está bem. Qualquer coisa eu volto a te ligar. Agora vai que eu tento... Mas se eu não tiver coragem, vai ficar lá... Vai fazer o que aí... Eu ligo para a Funabes.

A:-Qualquer coisa, pede para a gente ir no local. Vê se ele está passando mal e vê se ele quer vir para o hospital. Aí, eu mando a ambulância.

S: - Mas eu acho que ele não vai responder sinceramente... Mas em todo caso...

A: - Olha, faz o seguinte. Vê se tem alguém nesse bar, vê se tem alguma pessoa que pode ir lá mexer, vê se ele quer vir, vê se ele está passando mal. E se ele estiver passando mal, eu mando a ambulância. E a senhora me dá o retorno.

S: - Está bom, obrigada.

A: - De nada!

$(\mathrm{A}=$ Atendente $; \mathrm{S}=$ solicitante $)$

OBS: os nomes aqui utilizados são fictícios.

Essas conversas telefônicas mostram que, tanto para os atendentes quanto para os médicos e as recepcionistas do pronto-socorro, o tempo da manifestação do(s) sintoma(s) entra como um dado significativo na avaliação de urgência: "está com dores 
desde que horas?"; “ele está com falta de ar há quanto tempo?"; "está com esse problema há quanto tempo?"; "quando que começou?"; "ele tem sempre?"; "é a primeira vez?". Um problema encarado a priori como sério (desmaio, membro quebrado, febre alta, dores no peito) tende a ser considerado menos grave e urgente quando não acabou de surgir, ${ }^{8}$ sempre conforme o mesmo raciocínio: já que esperou até agora, pode esperar "mais um pouco".

Essas ligações também indicam a dificuldade de os atendentes obterem as informações, mesmo que mínimas, que precisam para avaliar o problema de saúde e mandar uma ambulância ao local. Raramente o solicitante é o paciente ou mesmo alguém de sua família. É um vizinho, ou ainda um desconhecido, que sabe pouco ou nada da pessoa para quem chama: nem de sua situação habitual de saúde - se está sofrendo de uma doença, seguindo um tratamento -, nem do problema que motiva a chamada de uma ambulância.

Várias razões ajudam a entender o porquê. Quem liga para a Central muitas vezes tem um telefone em casa: simples morador, dono de loja ou de bar, alguém chega de repente avisando-o que é para ligar urgente para a Central e vai embora sem deixar nenhuma outra informação. $O$ mesmo acontece com o solicitante que liga de um orelhão: os familiares (ou conhecidos) do doente ou do acidentado, naquela hora, muito preocupados e nervosos, pedem que ele chame o socorro; ou ele mesmo, participando da cena ou passando por lá, toma a iniciativa de chamar a Central. Assim, muitas vezes quando liga, não só ignora em grande parte o que aconteceu - "caiu", "está com dor", "está desmaiado"-, mas nem viu a pessoa para quem está solicitando a ajuda. Não sabe seu nome, apenas a conhece pelo apelido ou nem isso: "a gente chama ele de..."; "é um velho que mora do lado"; "é um moço que trabalha na construção do lado". Também não conhece o endereço exato: ${ }^{9}$

As vezes tem pessoas que ligam aqui apavoradas, eu pergunto para a pessoa, 'eu sou o vizinho, não sei te responder o que está acontecendo'. Então, nesses casos, a gente tenta, da pessoa que é a vizinha, tenta... A pessoa tenta responder melhor o que está acontecendo com a pessoa, lá, na residência. Quando não tem jeito, eu falo, 'tudo bem senhor', eu anoto o endereço certinho, o nome do vizinho, às vezes, o vizinho não sabe do nome completo do seu vizinho, não sabe nem o que está acontecendo com ele. Só falou com um parente lá na casa dele, pediu para socorro... então, às vezes, eu anoto e mando a ambulância. Mas antigamente, quando não tinha rádio, aí ficava dificil. Mas como tem rádio agora, o motorista chegando no local, às vezes, eu pergunto para o motorista o que está acontecendo realmente. 'Será que é aquilo mesmo que estava acontecendo no telefone?'. Eu tento fazer o máximo para uma pessoa me responder realmente o que aconteceu... o tipo de caso clinico que ela tem ou o caso mais grave que aconteceu com ela. Agora quando é um parente, ai fica mais fácil, posso perguntar o que está acontecendo. Ai, a pessoa sabe te responder. A coisa mais dificil é quando é vizinho. (Atendente 1)

Pior ainda para os atendentes são as pessoas que solicitam uma ajuda para desconhecidos que descrevem, geralmente, como estando "deitados ("desmaiados", "caídos") na rua" e com quem não ousam entrar em contato (com a fala ou com o toque). 
Essas chamadas são numerosas, e o Exemplo 6 é representativo do comportamento comum dos solicitantes nesse tipo de situação:

Casos que eu pego mais, também, são os de alcoolizados que caem na nua. Ás vezes eles falam, 'ah, está desmaiado!', 'bebeu bastante aqui, encheu a cara, está desmaiado'. Tento tirar mais do solicitante, se ele está meio desmaiado, se faz tempo que ele está caído. Porque, às vezes, a pessoa passa na rua, o primeiro passa, vê, 'ah, deixa lá, deve estar dormindo!', então não tem aquela solidariedade, vontade de ajudar a pessoa. E, às vezes, quando a outra passa, 'ah, não, vou ajudar, vou ligar!' 'Ai você pergunta: 'você conhece?', 'ah, não, é um andarilho, anda na rua, não sei quem que é!'. 'O senhor sabe mais ou menos desde que horas ele está caido?'. 'Não, passei agora, estou vendo agora, então não sei desde que horas ele está caído là'. Então eu pergunto para a pessoa: 'não tem condição de você chamar ela, para ver se ela está dormindo, ver se ela está descansando?'. Às vezes ela bebeu um pouquinho só, então deitou para dormir. 'Ah, moço! Estou com medo de chegar perto'. Isso que fica para a gente. Então você não sabe se está realmente desmaiado, se está em coma, se está apenas descansando. (Atendente 1)

Quando os solicitantes são familiares, os atendentes obtêm geralmente os dados dos quais precisam: endereço, identidade, problema do paciente, sua situação de saúde e histórico, tipos de remédios que eventualmente toma etc. Mesmo assim, não é sempre simples e nem rápido. Sendo os solicitantes emocionalmente envolvidos na situação, torna-se difícil conseguir deles a calma necessária para a obtenção das informações. Aflitos, pedem socorro de maneira reiterada sem responder às perguntas do atendente, repetindo sem parar as mesmas frases desesperadas como "vai morrer, venha pelo amor de Deus!"; "faça alguma coisa, que ele vai morrer. Ah, meu Deus!".

Além do mais, os familiares nem sempre revelam o verdadeiro laço que os une ao paciente: querendo ocultar sua verdadeira identidade, escondem-se atrás da figura de um vizinho ou de um conhecido hipotético. São pessoas que não querem que seu parente saiba de sua ligação ao 192, geralmente para não sofrer represálias quando este voltar. Acontece em famílias que querem se livrar temporariamente de um dos seus membros cuja presença e/ou comportamento perturbam ou ameaçam seriamente a vida dos outros: pode ser o filho que se droga; o marido que bebe; a filha que, por ter problemas psiquiátricos sérios, exige muita atenção; o sogro cujo estado de saúde necessita muitos cuidados e gastos, para citar alguns exemplos correntes.

Importa ressaltar que todos os solicitantes têm dificuldade de descrever o que está acontecendo com a pessoa para quem pedem a intervenção do 192; qualquer seja a natureza de seu laço com ela. Suas respostas são breves, suas descrições gerais e sumárias. "Tento tirar [os dados] do solicitante", dizem os atendentes que têm de insistir. A pobreza e a limitação das falas (em termos de vocabulário e de expressão) na descrição dos sintomas, das sensações, também foram apontadas nas conversas entre os usuários e as recepcionistas do pronto-socorro. 


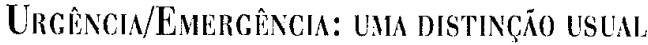

Os atendentes usam espontaneamente os termos 'urgência' e 'emergência', mas não discorrem sobre a distinção a ser feita entre as duas, nem sobre sua necessidade. Designam por 'urgência' os casos que, ao seu ver, 'podem esperar' e por 'emergência', os que consideram muito urgentes por serem graves (virem a se tornar se não forem atendidos com rapidez). Dito isto, a observação da rotina do 192 acaba revelando que, fora os casos severos que fazem entrar na categoria das ditas 'emergências', os atendentes consideram 'urgências' todos os problemas para os quais mandam uma ambulância, mesmo se não os acham graves, mas até corriqueiros:

Tudo que sai daqui, essas chamadas, para nós é uma urgência. A partir do momento que a ambulância chega no local, ela vai constatar se é uma urgência ou emergência. Aí, no caso, é quem está no local que comprova no local. Para mim, tudo é uma urgência. A partir do momento que sai daqui, é uma urgência. (...) Pelo que a pessoa me liga e fala, casos que você sabe que é urgente, o veiculo tem que sair mesmo, coisas assim graves, tipo enfarte, tipo parada cardiaca, hemorragia, coisas assim, que levam risco de vida da pessoa. Então, ai você manda assim rapidinho. Mas tudo é uma urgência! Uma vez lá é que a pessoa vai constatar se é emergência ou urgência. (...) Emergência mesmo, acho que são uns $30 \%$ O resto são coisas corriqueiras, bêbados ou dor de cabeça. Bêbados é direto. (Atendente 2)

Emergência para mim, é enfarte, quando a pessoa já está ou no principio de enfarte ou já está num estágio mais avançado. Ela está com cianótica, roxeando, ai é parte de emergência. Ai, na hora. Mando [a ambulância] na hora. E ai, enquanto eu mando a ambulância, a pessoa vai me dando os dados, aí, vou anotando o resto. Quando a gestante também já está na parte... quase... dando a luz à criança, para mim já é uma emergência também. Todo caso grave mesmo que você vê por telefone com a pessoa, a pessoa conversando com você, vê que ela está assim apavorada, desesperada, você vê que é uma emergência, você manda na hora. Para mim, são uma emergência esses casos. Agora, urgência, urgência é mais assim... não é tão grave, dá para aguardar um pouco ainda, esperar a ambulância chegar, ou senão passar para o motorista do trânsito... Uma cólica de rim pode ser uma emergência quando a pessoa está, não está agüentando mais, quando já esiá desmaiando de dor. Ai, pode ser una emergência também. Agora, uma cólica de rim que dá para agüentar mais que uma meiahora, já para mim, já é uma urgência. Emergência é mais aquele estado grave mesmo, que não tem... que a urgência não, a urgência é mais como... comę̧ou agora ou dá para agüentar mais um pouco, ai já é uma urgência (...) O certo disso daqui [a Central], era só emergência mesmo, só emergência ... parto... só emergência. Não pegar esses casinhos de posto de saúde que não funciona. Eu peguei agora um posto de saúde aqui, do São Judas, que vai ter médico só às cinco da tarde. E a criança está com bronquite, eles não fazem inalação sem receita médica. Então fica dificil para a gente trabalhar aqui. A maioria dos casos clínicos que você pega é dor de cabę̧a, diarréia, vômito... Nesses casos, não precisa nem vir de ambulância, tinha que ir no posto de saúde, o médico consultar e mandar para a casa. Posto de saúde de Marilia não funciona, então 
não tem como você fazer emergência com isso daqui. Às vezes, aparece uma emergência, mas às vezes não... às vezes não é nada. Emergência mesmo, depende, emergência, emergência, uns 10\%. O que dá mais é gestante, 50\%, metade, o que pego mais mesmo é gestante. É porque o hospital não tem leito, eles mandam embora, chegam em casa, a pessoa passa mal. (Atendente 1)

\section{Leque dos InFORTÚNIOS: AS URGÊNCIAS dO 192}

Os discursos dos atendentes traduzem uma realidade: a Central atende numerosos casos que não têm muito a ver com sua função declarada, que é prestar socorro, por meio de suas ambulâncias e motoristas, a pessoas cujo estado de saúde justifica. Seus veículos servem para o transporte de muitos usuários que, se não fosse sua situação não tanto de saúde mas econômica - não recorreriam a eles. Da mesma maneira, se várias instituições - postos de saúde, serviço social, hospital público, entre outros cumprissem com eficiência suas funções declaradas, muitos dos pedidos recebidos pela Central deixariam de existir.

Os próprios atendentes da Central de chamadas dos bombeiros repassam para a Central de Ambulâncias os pedidos de ajuda relativos a 'casos clínicos' que, no seu ver, não exigem a intervenção do Resgate por não se tratarem de emergências. O 193 atua sobretudo em acidentes (de trânsito), e acabam caindo no 192 todas as outras solicitações que dizem respeito à esfera ampla dos problemas de saúde, muitas vezes entrelaçados a problemas e dificuldades de natureza social.

Da mesma maneira, a Central da Polícia, o 190, repassa para a Central de Ambulâncias, todas as chamadas relativas a situações de violência que envolvem pacientes ditos 'alcoolizados', 'drogados' e 'psiquiátricos'. Nesses casos, o 192 há de atuar primeiro no lugar, isto é, um de seus motoristas, às vezes acompanhado pelo chefe da Central. ${ }^{10} \mathrm{~A}$ polícia intervém em um segundo momento, se o motorista ligar pedindo sua ajuda. ${ }^{11}$ Esse esquema visa a proteger a polícia, cuja responsabilidade seria implicada se o paciente, indo com ela ao pronto-socorro, se machucasse durante seu transporte. Por isso, é levado de ambulância.

À diferença de seus colegas do 193 e do 190 , os atendentes do 192 não têm como se livrar dos pedidos de ajuda relativos a problemas de saúde, que fogem de sua esfera declarada de competência (atender às urgências e às emergências), encaminhando-os para outros profissionais, ${ }^{12}$ pois não existe outra instância suscetível de oferecer ou negar um atendimento, isto é, de tomar a decisão e de responder por ela. E como os atendentes da Central de Ambulâncias estão, ao mesmo tempo, preocupadissimos com a implicação de sua responsabilidade nas decisões tomadas, e inseguros na triagem pela qual não se sentem muito qualificados, preferem atender aos pedidos mandando uma ambulância, do que arcar com as conseqüências de um possível erro. Temem que os pacientes ou sua familia entrem com processo por omissão de socorro e, para justificar sua postura, citam espontaneamente histórias de pessoas que, não atendidas porque seu caso não foi levado a sério, morreram, especialmente alcoólatras caídos na rua: 
Na dívida, eu mando [a ambulância] do mesmo jeito. Pode estar dormindo, pode estar desmaiado... Porque se acontecer alguma coisa, quem tem que... a culpa vai vir do triador. Nunca se sabe. Igual esse paciente, ele é psiquiátrico, quer dizer, ele era..., ele tomava Aquineton, Aldose, aqueles remédios fortes e ele bebia por cima. E ele ia direto para o hospital, a gente pegava ele por dia... acho que eu pegava quatro vezes por dia. O médico vai lá, tenta segurar a pessoa, tipo... vai lá [para o pronto-socorro], vai embora, toma de novo. Então, esse paciente deu o maior.. Porque ele estava caido de manhã na Vila Real, a gente foi buscar ele, ai levamos para o hospital. Só que acabou de sair do hospital, já vai andar para a rua e bebe de novo... pede esmola para as pessoas, vai beber de novo. Ele caiu mais uma vez, os colegas de bar não prestaram atenção, não chamaram a ambulância, ficou horas assim, e quando finalmente a ambulância chegou, estava morto desde várias horas. Os colegas disseram que tinham chamado a ambulância desde o início mas que não veio, o que é falso. (Atendente 1)

\section{E, mais adiante:}

Igual o tal do Resgate lá. Morreu um rapaz lá na... Salgueiro, a familia está... Porque disse [o triador do Resgate quando ligou a familia] que não tinha ambulância dentro da hora, que ela estava em ocorrência, mas acho que não estava lá, acho que eles não mandaram porque acharam que não era grave. Ea pessoa morreu... Eles estão com medo mesmo de ter acontecido. (...) A familia pode processar depois ou pedir indenização... Isso daqui [a triagem] é responsabilidade mesmo. (Atendente 1)

Afinal, o 192 aparenta-se mais a um serviço social, que, por oferecer atendimento à população $24 \mathrm{~h}$ por dia, acaba preenchendo, na precariedade, vácuos existentes no domínio da ajuda social, espaços deixados vazios por outros agentes e instituições de serviço público.

Pelo tipo de pedidos que recebe, pelas necessidades a ela expressas e pelas pessoas que solicitam suas ambulâncias, a Central reflete, ainda mais do que o prontosocorro, o desamparo e a carência de recursos das populações de baixa renda. Ela é o espelho do infortúnio social e individual, cujos problemas de saúde, entendidos no sentido estrito da saúde anatomofisiológica, só representam uma faceta. Na frente dessa demanda poliforma e dentro de um contexto de escassez, o 192 acaba atendendo quase todas as solicitações.

Como já foi indicado no Capitulo 3 , a triagem na Central se realiza menos na seleção dos casos a serem atendidos do que no tempo que leva até ser prestado o atendimento: é mais pela inscrição, na dimensão do tempo, da ordem das prioridades, que ela se concretiza. 


\section{Notis}

1 Da mesma maneira que os seguranças, porteiros e recepcionistas do pronto-socorro.

2 Trata-se de pacientes cuja solicitação de ajuda foi feita por alguém da família, da vizinhança ou por um desconhecido, e que se recusam a ir para o pronto-socorro, uma vez a ambulância no lugar.

3 Do conjunto das ambulâncias, geralmente duas funcionam, às vezes só uma e nos melhores dias, três.

4 Como, por exemplo, retorno médico, transporte de um paciente ou/e do seu acompanhante do hospital para a casa. Como o Bem-Estar Social fecha às $17 \mathrm{~h}$ e que seu serviço de ambulância pára de funcionar às $19 \mathrm{~h}$, a partir desse horário e a noite toda, a Central de Ambulância passa a assumir a tarefa de transporte de pacientes (e acompanhantes). O mesmo acontece aos sábados e domingos, dias em que o BemEstar Social está fechado.

5 Anotam esses elementos em uma ficha que o motorista pega no momento da saída, na qual ele inscreve seu nome, suas observações e assina uma vez de volta na Central onde a ficha fica arquivada.

6 A mesma constatação foi feita com os seguranças do pronto-socorro.

7 O paciente tem de ser acompanhado.

8 Exceto no caso de mulheres grávidas de 9 meses que se queixam de dores fortes há muitas horas.

9 Não conhece o nome da rua, ou o número, e indica um edifício que está do lado, um ponto que, para quem é do bairro, constitui uma referência visual.

10 Acontece quando a situação, tal como foi descrita no telefone, deixa supor que a intervenção de um motorista só não será suficiente (conter uma pessoa violenta e amarrá-la na maca para efetuar seu transporte até o pronto-socorro, por exemplo).

11 O documentário etnográfico Urgences (Giglio-Jacquemot, 2002) mostra esse procedimento em ação.

12 Como, por exemplo, na França, onde os atendentes das centrais de chamadas do Serviço Público de Ajuda Médica de Urgência (Samu-Centre 15) podem pedir, por exemplo, ao solicitante para ligar para médicos de plantão da cidade que atendem o paciente em seu domicílio, quando estimam que o caso não justifica sua intervenção. 